\title{
Nodulation, nitrogen uptake and growth of lima bean in a composted tannery sludge-treated soil
}

\section{Sandra Mara Barbosa Rocha ${ }^{1}$ Jadson Emanuel Lopes Antunes ${ }^{1}$ \\ Antonio Victor Cavalcante Rocha Silva ${ }^{1}$ Louise Melo de Souza Oliveira ${ }^{1}$ \\ João Pedro Alves de Aquino ${ }^{1}$ Wanderley Jose de Melo $^{2,3}$ Marcia do Vale Barreto Figueiredo ${ }^{4}$ Ademir Sérgio Ferreira de Araujo ${ }^{1^{*}}$}

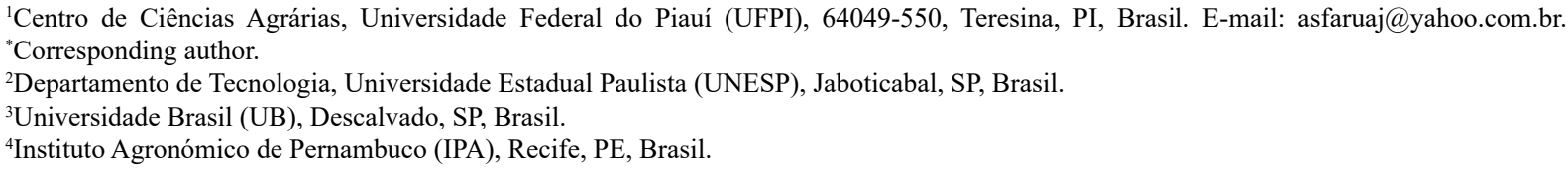

ABSTRACT: This study evaluated the responses of lima bean (Phaseolus lunatus L.) to application of composted tannery sludge on nodulation, $N$ uptake and plant growth. For eight years, the compost was applied at rates of: 0, 2.5, 5, 10, and $20 \mathrm{Mg} h \mathrm{a}^{-1}$ (dry basis). Plants of lima bean showed higher nodulation in treatments with compost; however, nodules reported in these treatments presented lower biomass, size and diversity than those reported in treatment without compost. Accumulation of $\mathrm{N}$ increased with the application of the highest rate $\left(20 \mathrm{Mg} \mathrm{h} \mathrm{C}^{-1}\right)$, while there was an increase in chromium content in shoot with the increase in compost rates. Thus, the use of composted tannery sludge, in long-term, increases the accumulation of chromium in plants, increasing nodulation, while decrease rhizobia diversity in nodules.

Key words: chromium, industrial waste, Phaseolus lunatus, biological $N$ fixation.

\author{
Nodulação, absorção de nitrogênio e crescimento de feijão-fava \\ em solo tratado com lodo de curtume compostado
}

RESUMO: Este estudo avaliou a resposta do feijão-fava (Phaseolus lunatus L.) a aplicação de lodo de curtume compostado na nodulação,

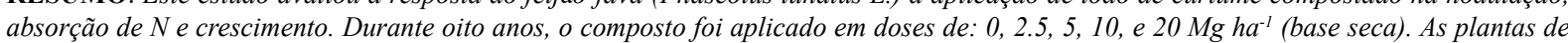
feijão-fava mostraram maior nodulação nos tratamentos com o composto. Entretanto, os nódulos encontrados nestes tratamentos apresentaram menor biomassa, tamanho e diversidade do que os observados no tratamento sem composto. A acumulação de N aumentou com a aplicação da maior dose do composto $\left(20 \mathrm{Mg} \mathrm{ha}^{-1}\right)$, enquanto que houve um aumento nos teores de crômio na parte aérea com o aumento das doses do composto. Desta forma, o uso do lodo de curtume compostado, em longo prazo, aumenta a acumulação de crômio, aumentando a nodulação, enquanto diminui a diversidade de rizóbios nos nódulos.

Palavras-chave: cromio, resíduo indutrial, Phaseolus lunatus, fixação biológica do $N$.

\section{INTRODUCTION}

Tannery sludge (TS), a waste generated by tannery industries, contains high content of organic matter and chemical elements that could be used for agriculture as soil conditioners as an alternative method for improving soil properties (SHARMA et al., 2017). Although, TS could be suggested for applying in agricultural soils, its high content of chromium $(\mathrm{Cr})$ can accumulate in soil and pollute the environment. Therefore, a previous treatment of TS could be necessary before its use in soil. As an alternative and suitable method, composting has been used as a pre-treating method of TS before its application in the soil since this biological process could decrease the content of $\mathrm{Cr}$, through the microbial metabolism, and also improve the quality of the waste and consequently of soil (SOUSA et al., 2017). Indeed, application of composted tannery sludge (CTS) may contribute for improving the content of organic matter and soil fertility (ARAÚJO et al., 2013). Also, CTS has positively influenced the growth and yield of crops (SOUSA et al., 2017). However, applications of CTS have negatively increased $\mathrm{Cr}$ accumulation in soil (ARAÚJO et al., 2013).

Accumulation of $\mathrm{Cr}$ in soil can cause damage to both rhizobia and legumes, and also their 
symbiosis. Therefore, the use of CTS, in long-term, increasing the $\mathrm{Cr}$ content in soil could affect the rhizobia-legumes symbiosis, known as biological $\mathrm{N}$ fixation (BNF). This process is carried out by rhizobia in the rhizosphere and contributes for the availability of $\mathrm{N}$ to legume plants. This process occurs in root nodules, being the nodulation a suitable indicator of efficient BNF (PEOPLES et al., 1989) and also there is a significant correlation between nodulation and efficiency of $\mathrm{N}$ fixation in legumes (DELIC et al., 2010). Also, nodulation and BNF are important parameters for evaluating toxic effects of pollutants (MIRANDA et al., 2014).

Although, CTS has favored the plant growth and improved soil fertility, the effect of permanent application of CTS and the increased $\mathrm{Cr}$ accumulation in soil on nodulation and BNF are not clear. In short-term, MIRANDA et al. (2014) reported that nodulation and BNF in cowpea were not negatively affected by CTS and $\mathrm{Cr}$ accumulation in soil. However, it remains unclear how would be the responses of others legume to application of CTS, mainly in long-term, on nodulation and BNF. Therefore, the lima bean (Phaseolus lunatus L.), a legume plant highly resistant to adverse condition, was used for evaluating the effect of CTS, after eight years of application, on nodulation and BNF. This study aimed to evaluate the nodulation and $\mathrm{N}$ fixation in lima bean as response to application of CTS.

\section{MATERIALS AND METHODS}

The study was conducted in a greenhouse located at Agricultural Science Center of Federal University of Piaui, Brazil $\left(05^{\circ} 05^{\prime} \mathrm{S}\right.$; $42^{\circ} 48^{\prime} \mathrm{W}$, $75 \mathrm{~m}$ ). Soil samples used in this experiment were collected, at $0-20 \mathrm{~cm}$ depth, from a long-term experimental field with application of CTS $(0,2.5$, 5, 10, and $20 \mathrm{Mg} \mathrm{ha}^{-1}$; dry basis) for eight years. The detailed description of this long-term study and also the chemical properties of CTS can be found in SOUSA et al. (2017).

For this study, pots $(2.8 \mathrm{~L})$ were filled with soil collected from the experimental plots with CTS. The experiment design was completely randomized with four replicates. The chemical properties of soil were determined according to DONAGEMA et al. (2011). Soil Cr was extracted by the DTPA-TEA method and measured using the USEPA-3050 method (USEPA, 1996). Briefly, $1 \mathrm{~g}$ of soil (dry weight) was digested with repeated additions of nitric acid $\left(\mathrm{HNO}_{3}\right)$ and hydrogen peroxide $\left(\mathrm{H}_{2} \mathrm{O}_{2}\right)$. The resultant solution was reduced in volume, while heating and then diluted to a final volume of $100 \mathrm{~mL}$. Extracts were analyzed by using inductively coupled plasma mass spectrometry (ICP-MS).

Seeds of lima bean were superficially disinfested with alcohol (70\% for $30 \mathrm{~s})$ and sodium hypochlorite ( $2 \%$ for $5 \mathrm{~min}$ ). Afterward, the seeds were successively washed with sterilized water. Five seeds were sowed per pot and, after seven days from germination, two plants were left in each pot. A N-free nutritive solution was used for the irrigation of plants during the experiment in the rate of $2 \mathrm{~mL} \mathrm{~kg}^{-1}$ soil.

Nodules and plant measurements were done 45 days after plant emergence (plant flowering). Nodules and plant shoots were dried $\left(65^{\circ} \mathrm{C} ; 72 \mathrm{~h}\right)$ and weighed to determine both the nodules (NDW) and shoot dry weight (SDW). Nodules were counted and their sizes were estimated by using the ratio between nodule dry weight and number (TEIXEIRA et al., 2006). Total $\mathrm{N}$ content in shoot was estimated by Kjedahl method (DONAGEMA et al., 2011). The accumulation of $\mathrm{N}(\mathrm{AcN})$ in shoot was estimated by the SDW and total N content (KEENEY \& NELSON, 1982). Chromium content in shoot was estimated according to the method described in USEPA-3050 (USEPA, 1996).

Three nodules in each pot were sampled for obtaining bacterial isolates. For that, nodules were sterilized with sodium hypochlorite $(0.1 \%$; $\mathrm{w} / \mathrm{v}$ for $5 \mathrm{~min})$ and ethanol ( $95 \%$; v/v for $10 \mathrm{~s})$, being washed with distilled water. Afterward, the nodules were streaked on a medium (yeast-extract mannitol agar) containing $0.0025 \%(\mathrm{w} / \mathrm{v})$ of Congo red. After fifteen days, single colonies were selected and restreaked on the same medium for purification. The morphological and physiological characteristics (MELLONI et al., 2006) of each isolate were used for calculating the diversity of rhizobia isolates by the Shannon index. It was calculated according to the following way:

$\mathrm{H}^{\prime}=-\sum \mathrm{p}_{i} \ln \mathrm{p}_{i}$

where $\mathrm{p}_{i}$ is the proportion of isolates presenting the characteristics $i$. The proportion was estimated as $\mathrm{p}_{i}=\mathrm{n}_{i} / \mathrm{N}$, where $\mathrm{n}_{i}$ is the number of isolates presenting the characteristics $i$ and $\mathrm{N}$ is the total number of isolates.

The data were submitted to analysis of variance (ANOVA), proceeded by $\mathrm{F}$ test $(\mathrm{P}<0.05)$ by using Assistat 7.6 beta. Spearman's rank correlation coefficients were calculated to explore the relationship between biological variables and environmental factors according to the different treatments using the 'multitest' package in R. 


\section{RESULTS AND DISCUSSION}

Application of composted tannery sludge changed the chemical properties of the soil (Table 1). The values of soil $\mathrm{pH}, \mathrm{TOC}, \mathrm{P}$ and $\mathrm{Ca}$ increased 1.5 , 2.2, 5.2 and 13.3 units from 0 to $20 \mathrm{Mg} \mathrm{ha}^{-1} \mathrm{CTS}$, respectively. Markedly, the values of $\mathrm{Cr}$ increased 150.1 units from the untreated soil $\left(0 \mathrm{Mg} \mathrm{ha}^{-1}\right)$ to the highest CTS rate $\left(20 \mathrm{Mg} \mathrm{ha}^{-1}\right)$.

The composition of composted tannery sludge shows high concentrations of organic C, $\mathrm{P}$, $\mathrm{Ca}$, and $\mathrm{Cr}$ (SOUSA et al., 2017) and; consequently, the permanent application of this waste increases the values of $\mathrm{pH}, \mathrm{TOC}, \mathrm{P}, \mathrm{Ca}$ and $\mathrm{Cr}$ in soil. Positively, the increase in the content of organic $\mathrm{C}, \mathrm{P}$ and $\mathrm{Ca}$ is important for soil fertility and plant growth. However, the increase of soil $\mathrm{pH}$ can bring negative consequences on the availability of some plant nutrients. Another important concern is about the increase in Cr content, mainly at the highest CTS rates, since this metal can, negatively, influence the nodulation and plant growth (STAMBULSKA et al., 2018).

The plants showed highest number of nodules in treatments with 10 and $20 \mathrm{Mg} \mathrm{ha}^{-1} \mathrm{CTS}$ (Figure 1a). However, nodules reported in plants under the application of CTS presented the lowest dry weight (Figure 1b) and size (Figure 1c) as compared with the treatment without CTS. Also, the diversity rhizobia isolates, estimated by Shannon index, decreased in treatments with 10 and $20 \mathrm{Mg}$ ha $^{-1}$ CTS (Figure 1d).

Application of composted tannery sludge increased the number of nodule in lima bean. However; although, soils with the application of CTS stimulated the nodulation, the nodules reported in CTS-treated soils were smallest and with a reduced diversity than the untreated soil. Conversely, the stimulation of nodulation may have occurred, probably, due to the presence of bacteria in the compost that may have increased the infection in the roots. Indeed, DANON et al. (2008) have reported a bacterial community colonizing the organic compost with high abundance of Proteobacteria. According to BOMFETI et al. (2011), bacteria from the group of Proteobacteria are able to form nodules on legume plants. Conversely, the chromium content increased in soil with application of CTS and it may have resulted in fewer bacterial colonization and smaller size of nodules.

The presence of many small nodules reported in treatments with CTS could reduce the efficiency of BNF due to adverse conditions to rhizobia. Also, the presence of $\mathrm{Cr}$ can inhibit the activity of nitrogenase in nodules decreasing the intensity of $\mathrm{N}$ fixation (STAMBULSKA et al., 2018). Nodules reported in the treatments with CTS presented lowest Sahnnon's index suggesting some negative effect on the morphological and physiological characteristics of rhizobia. Thus, the application of CTS could, probably, contributed to select adapted rhizobia to adverse conditions promoted by the waste. Indeed, the evaluation of morphological and physiological characteristics of rhizobia isolates showed that the diversity of rhizobia decreased from treatments without CTS $\left(0 \mathrm{Mg} \mathrm{ha}^{-1}\right)$ to the highest CTS rate $\left(10\right.$ and $\left.20 \mathrm{Mg} \mathrm{ha}^{-1}\right)$; i.e., the application of CTS, at the highest rates, contributed for increasing the uniformity of morphological and physiological characteristics of isolates, so decreasing their diversity.

Although, plants under the highest CTS rates $\left(20 \mathrm{Mg} \mathrm{ha}^{-1}\right)$ have presented the lowest nodule biomass and size, they accumulated more $\mathrm{N}$ (Figure 2a) and shoot biomass (Figure 2b) than the plants without CTS. Also, the application of CTS contributed for increasing $\mathrm{Cr}$ content in shoot with the increased CTS rates (Figure 2c). Application of CTS,

Table 1 - Chemical properties of the soil after eight years of consecutive application of composted tannery sludge (CTS).

\begin{tabular}{|c|c|c|c|c|c|c|c|c|c|}
\hline CTS $\left(\mathrm{Mg} \mathrm{ha}^{-1}\right)$ & $\mathrm{pH}$ & $\mathrm{EC}$ & TOC & $\mathrm{P}$ & $\mathrm{K}$ & $\mathrm{Ca}$ & $\mathrm{Mg}$ & $\mathrm{Na}$ & $\mathrm{Cr}$ \\
\hline & $\mathrm{CaCl}_{2}$ & $\mathrm{dS} \mathrm{m}^{-1}$ & $\mathrm{~g} \mathrm{~kg}^{-1}$ & $\mathrm{mg} \mathrm{dm}^{-3}$ & \multicolumn{4}{|c|}{ 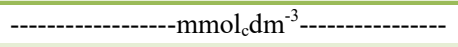 } & $\mathrm{mg} \mathrm{kg}^{-1}$ \\
\hline 0 & $5.1^{\mathrm{d}}$ & $0.5^{\mathrm{a}}$ & $4.9^{\mathrm{d}}$ & $4.3^{\mathrm{d}}$ & $1.9^{\mathrm{a}}$ & $12.5^{\mathrm{d}}$ & $5.0^{\mathrm{b}}$ & $4.4^{\mathrm{a}}$ & $5.8^{\mathrm{e}}$ \\
\hline 2.5 & $5.4^{\mathrm{d}}$ & $0.5^{\mathrm{a}}$ & $5.7^{\mathrm{c}}$ & $5.0^{\mathrm{c}}$ & $1.8^{\mathrm{a}}$ & $17.0^{\mathrm{c}}$ & $5.8^{\mathrm{b}}$ & $4.9^{\mathrm{a}}$ & $27.2^{\mathrm{d}}$ \\
\hline 5 & $5.8^{\mathrm{c}}$ & $0.5^{\mathrm{a}}$ & $6.8^{\mathrm{b}}$ & $6.0^{\mathrm{b}}$ & $1.9^{\mathrm{a}}$ & $22.8^{\mathrm{b}}$ & $7.0^{\mathrm{a}}$ & $4.9^{\mathrm{a}}$ & $58.0^{\mathrm{c}}$ \\
\hline 10 & $6.2^{\mathrm{b}}$ & $0.6^{\mathrm{a}}$ & $6.6^{\mathrm{b}}$ & $7.8^{\mathrm{b}}$ & $1.9^{\mathrm{a}}$ & $23.5^{\mathrm{b}}$ & $7.5^{\mathrm{a}}$ & $4.6^{\mathrm{a}}$ & $96.6^{\mathrm{b}}$ \\
\hline 20 & $6.6^{\mathrm{a}}$ & $0.6^{\mathrm{a}}$ & $7.1^{\mathrm{a}}$ & $9.5^{\mathrm{a}}$ & $1.8^{\mathrm{a}}$ & $25.8^{\mathrm{a}}$ & $7.0^{\mathrm{a}}$ & $4.9^{\mathrm{a}}$ & $165.9^{\mathrm{a}}$ \\
\hline
\end{tabular}

$\mathrm{EC}$ - electric conductivity; TOC - total organic carbon. 

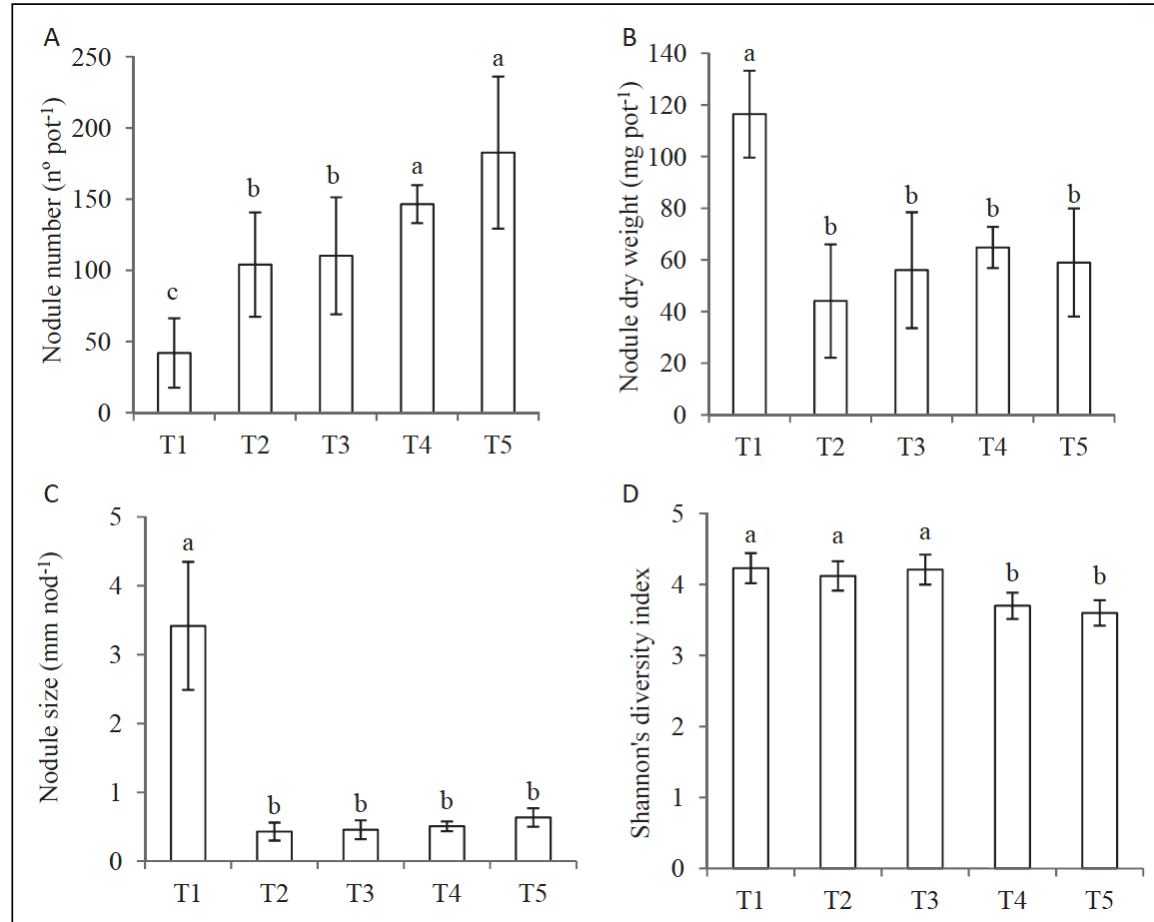

Figure 1 - Effect of composted tannery sludge (CTS) rates on nodule number (A), nodule dry weight (B), nodule size (C) and Shannon's diversity index (SDI) of rhizobia isolates in Lima bean grown in CTS-treated soils. T1 $=0 \mathrm{Mg}$ ha- $1 \mathrm{CTS}$; T2 $=2.5 \mathrm{Mg}$ ha-1 CTS; T3= $.0 \mathrm{Mg}$ ha- 1 CTS; T4=10 Mg ha-1 CTS; and T5 = $20 \mathrm{Mg}$ ha-1 CTS.

mainly in the highest rate $\left(20 \mathrm{Mg} \mathrm{ha}^{-1}\right)$, contributed for increasing the accumulation of $\mathrm{N}$ and it could be explained by the high content of organic matter reported in CTS-treated soils (Table 1) that may have contributed with $\mathrm{N}$ to plants. These results agreed with MIRANDA et al. (2014) that observed an increase on soil organic matter content, after application of composted tannery sludge, and; consequently, higher $\mathrm{N}$ availability to cowpea plants. Conversely, the $\mathrm{N}$ accumulated in plants from soil without CTS may be resulting of nitrogen fixation by native rhizobia since this soil does not present high organic matter content. This high accumulation of $\mathrm{N}$ presented by plants in the treatments with CTS, mainly at the highest rate $\left(20 \mathrm{Mg} \mathrm{ha}^{-1}\right)$, contributed to the differences in the shoot biomass of lima bean when compared to the treatment without CTS. Also, these results suggested that CTS promoted an increase in plant growth due to the availability of plant nutrients in the soil. Similar results were observed by MIRANDA et al. (2014) and SILVA et al. (2010) evaluating the effect of composted tannery sludge on the growth of cowpea and pepper, respectively.
The increase in $\mathrm{Cr}$ content in plants with the increasing of CTS rates reflects the pattern of $\mathrm{Cr}$ accumulation in soil after successive applications of CTS in long-term. Moreover, results indicated that there is a direct absorption of this element by lima bean similarly with the response cowpea and maize to CTS in a previous study (SOUSA et al., 2017). Also, LOPEZLUNA et al. (2012) have shown an accumulation of $\mathrm{Cr}$ in the shoot of common bean with the application of tannery sludge. In general, $\mathrm{Cr}$ uptake by the plants accumulates in the roots and forms barriers that diminish their translocation to the shoot (MOREIRA et al., 2013). The biological $\mathrm{N}$ fixation, being a process carried out at the root level, can be influenced by the excessive presence of $\mathrm{Cr}$ due to the alteration of the biochemical processes of the microorganisms and direct toxicity on Bradyrizobium (HUNGRIA \& VARGAS, 2000) and rhizobia symbiosis (STAMBULSKA et al., 2018). However, some metals play important functions during the establishment of BNF, such as $\mathrm{Fe}, \mathrm{Cu}, \mathrm{Zn}$ and Ni (GONZÁLEZ-GUERRERO et al., 2014), while $\mathrm{Cr}$ has presented negative effects on nodulation and BNF (STAMBULSKA et al., 2018). 


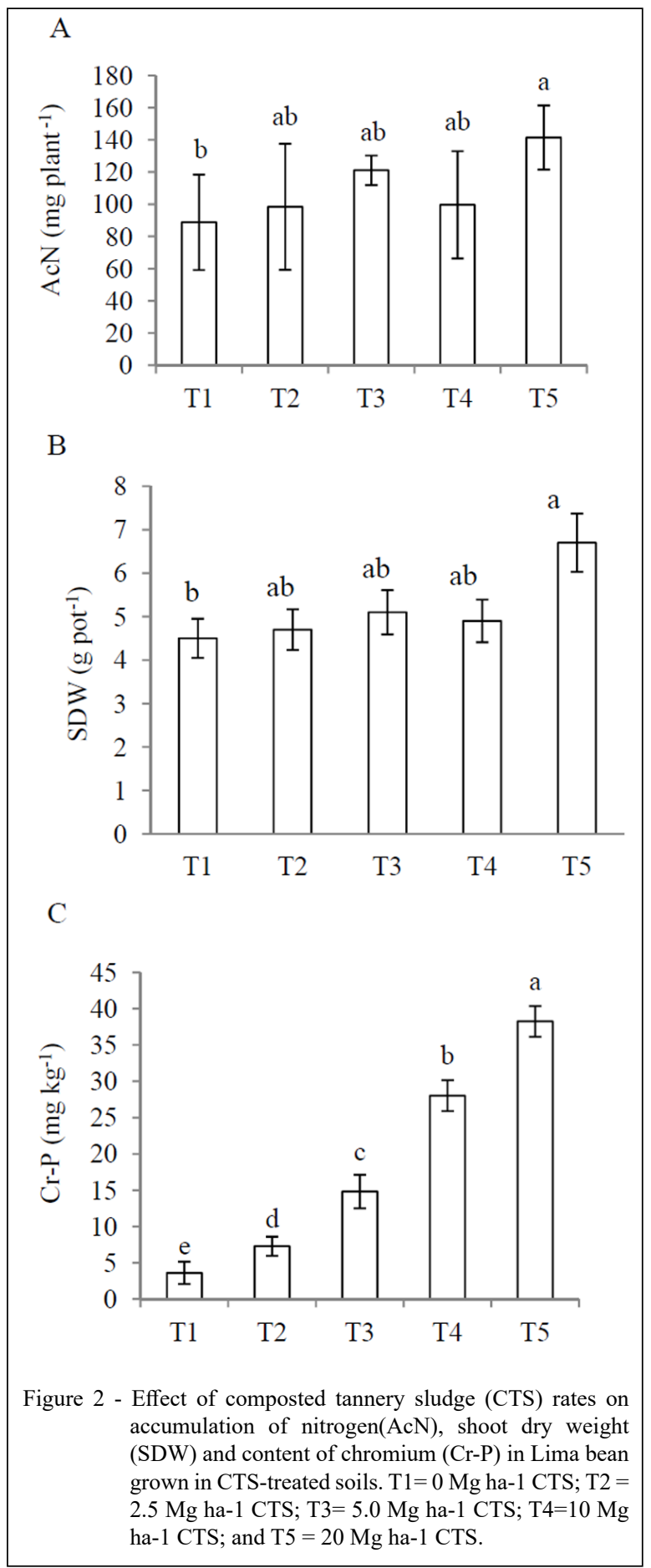

The analysis of Spearman's correlation (R) showed that the accumulation of $\mathrm{Cr}$ in shoot was positively correlated with chemical properties of soil, mainly soil $\mathrm{Cr}$ and $\mathrm{pH}$ (Table 2). On contrary, the diversity of rhizobia isolates showed a significant negative correlation with $\mathrm{CTS}$ rates, $\mathrm{Cr}$ and $\mathrm{pH}$ in soil. Results from the Spearman's correlation showed a significant negative effect of CTS, $\mathrm{pH}$ and, also $\mathrm{Cr}$ content in soil, on the diversity of rhizobia. This can be explained by the negative effect that these factors exert on the diversity of rhizobia, especially in tropical soils (HUNGRIA \& VARGAS, 2000). 
Table 2 - Spearman $(\mathrm{R})$ correlation values between composted tannery sludge(CTS) rates, plant variables and soil chemical factors. Only significant correlations $(\mathrm{P}<0.05)$ are presented in the table.

\begin{tabular}{|c|c|c|c|c|c|c|c|}
\hline & Cr-P & SDI & $\mathrm{NN}$ & NS & $\mathrm{AcN}$ & SDW & NDW \\
\hline CTS rates & 0.975 & -0.922 & 0.797 & & 0.472 & & \\
\hline $\mathrm{pH}$ & 0.963 & -0.906 & 0.754 & & & & \\
\hline $\mathrm{EC}$ & & & 0.537 & & & & \\
\hline TOC & 0.786 & -0.656 & 0.724 & & 0.490 & 0.471 & \\
\hline $\mathrm{P}$ & 0.795 & -0.704 & 0.823 & & 0.456 & & \\
\hline $\mathrm{Ca}$ & 0.832 & -0.745 & 0.799 & -0.486 & & & \\
\hline $\mathrm{Mg}$ & 0.587 & -0.478 & 0.686 & -0.523 & & & \\
\hline $\mathrm{Na}$ & & & & & & & -0.444 \\
\hline $\mathrm{Cr}$ & 0.943 & -0.902 & 0.797 & & & & \\
\hline
\end{tabular}

EC - electric conductivity; TOC - total organic carbon; $\mathrm{Cr}-\mathrm{P}$ - $\mathrm{Cr}$ in plant; SDI - Shannon's diversity index; number of isolates; NN nodule number; NS - nodule size; AcN - accumulated N; SDW - shoot dry weight; NDW - nodule dry weight.

Also, these factors may act on the rhizobia and their host affecting symbiosis, since abiotic factors such as $\mathrm{pH}$ and metals, such as $\mathrm{Cr}$, quantitatively and qualitatively alter the rhizobia population in the soil (STAMBULSKA et al., 2018).

\section{CONCLUSION}

The use of composted tannery sludge increases the accumulation of $\mathrm{Cr}$ in plants, increasing nodulation, while decrease rhizobia diversity in nodules. Positively, application of composted tannery sludge increases the accumulation of $\mathrm{N}$ and growth of lima bean, while that, negatively, there was an increase in the content of $\mathrm{Cr}$ in the plants.

\section{ACKNOWLEDGEMENTS}

We thank $\mathrm{CNPq}$ for financial support (Grant 305069/2018-7). Sandra M.B. Rocha and Jadson E. L. Antunes are supported by scholarship from Coordenação de Aperfeiçoamento de Pessoal de Nível Superior (CAPES). Ademir S. F. Araujo and Wanderley J. Melo are supported by Conselho Nacional de Desenvolvimento Científico e Tecnológico (CNPq).

\section{DECLARATION OF CONFLICT OF INTERESTS}

The authors declare no conflict of interest. The founding sponsors had no role in the design of the study; in the collection, analyses, or interpretation of data; in the writing of the manuscript, and in the decision to publish the results.

\section{AUTHORS' CONTRIBUTIONS}

All authors contributed equally for the conception and writing of the manuscript. All authors critically revised the manuscript and approved of the final version.

\section{REFERENCES}

ARAÚJO, A.S.F. et al. Soil pH, electric conductivity and organic matter after three years of consecutive amendment of composted tannery sludge. African Journal of Agricultural Research, v.8, p.1204-1208, 2013. Available from: <http://dx.doi.org/10.5897/ AJAR2013.7016>. Accessed: Mar. 10, 2019. doi: 10.5897/ AJAR2013.7016.

BOMFETI, C.A. et al. Exopolysaccharides produced by the symbiotic nitrogen-fixing bacteria of leguminosae. Revista Brasileira de Ciência do Solo, v.35, p.657-671, 2011. Available from: <https://dx.doi.org/10.1590/S0100-06832011000300001>. Accessed: Jul. 25, 2019. doi: 10.1590/S0100-06832011000300001.

DANON, M. et al. Molecular analysis of bacterial community succession during prolonged compost curing. FEMS Microbiology Ecology, v.65, p.133-144, 2008. Available from: <https://doi.org/ 10.1111/j.1574-6941.2008.00506.x>. Accessed: Jul. 25, 2019. doi: 10.1111/j.1574-6941.2008.00506.x.

DELIC, D. et al. Nodulation and $\mathrm{N}_{2}$ fixation effectiveness of Bradyrhizobium strains in symbiosis with Adzuki Bean, Vigna angularis. Brazilian Archives of Biology and Technology, v.53, p.293-299, 2010. Available from: <http://dx.doi.org/10.1590/ S1516-89132010000200007>. Accessed: Mar. 13, 2019. doi: 10.1590/S1516-89132010000200007.

DONAGEMA, G.K. et al. Manual de métodos de análise de solo, $2^{\mathrm{a}}$ ed. Embrapa Solos, Rio de Janeiro, 2011.

GONZÁLEZ-GUERRERO, M. et al. Fixating on metals: new insights into the role of metals in nodulation and symbiotic nitrogen fixation. Frontiers in Plant Science, v.5, p.45, 2014. Available from: < http://dx.doi.org/10.3389/fpls.2014.00045>. Accessed: Mar. 11, 2019. doi: 10.3389/fpls.2014.00045.

HUNGRIA, M.; VARGAS, M.A.T. Environmental factors impacting $\mathrm{N}_{2}$ fixation in legumes grown in the tropics, with an emphasis on Brazil. Field Crops Research, v.65, p.151164, 2000. Available from: <http://dx.doi.org/10.1016/S03784290(99)00084-2>. Accessed: Mar. 11, 2019. doi: 10.1016/S03784290(99)00084-2. 
KEENEY, D.R.; NELSON, D.W. Nitrogen. Inorganic forms. In: Page, A.L. (ed) Method of soil analysis chemical and microbiological. 2.ed. Madison, American Society of Agronomy, 1982. pp.643-693.

LOPEZ-LUNA, J. et al. Fractionation and availability of heavy metals in tannery sludge-amended soil and toxicity assessment on the fully-grown Phaseolus vulgaris cultivars. Journal of Environmental Science and Health A, v.47, p.405-419, 2012 Available from: <http://dx.doi.org/10.1080/10934529.2012.64612 1>. Accessed: Mar. 13, 2019. doi: 10.1080/10934529.2012.646121.

MELLONI, R. et al. Eficiência e diversidade fenotípica de bactérias diazotróficas que nodulam caupi [Vigna unguiculata (L.) Walp] e feijoeiro (Phaseolus vulgaris L.) em solos de mineração de bauxita em reabilitação. Revista Brasileira de Ciência do Solo, v.30, p.235-246, 2006. Available from: <http://dx.doi.org/10.1590/ S0100-06832006000200005>. Accessed: Mar. 12, 2019. doi: $10.1590 / \mathrm{S} 0100-06832006000200005$

MIRANDA, A.R.L. e al. Growth and nodulation of cowpea after 5 years of consecutive composted tannery sludge amendment. Spanish Journal of Agricultural Research, v.12, p.1175-1179, 2014. Available from: <http://dx.doi.org/10.5424/sjar/2014124 6282>. Accessed: Mar. 12, 2019. doi: 10.5424/sjar/2014124-6282.

MOREIRA, R.S. et al. Heavy metals availability and soil fertility after land application of sewage sludge on dystroferric red latosol. Ciencia \& Agrotecnologia, v.37, p.512-520, 2013. Available from: <http://dx.doi.org/10.1590/S141370542013000600004>. Accessed: Mar. 12, 2019. doi: 10.1590/ S1413-70542013000600004.

PEOPLES, M.B. et al. Methods for evaluating nitrogen fixation by nodulated legumes in the field. ACIAR Monograph 11.1989, 76p.
SHARMA, B.et al. Agricultural utilization of biosolids: A review on potential effects on soil and plant grown. Waste Management, v.64, p.117-132, 2017. Available from: <http://dx.doi.org/10.1016/j. wasman.2017.03.002>. Accessed: Mar. 13, 2019. doi: 10.1016/j. wasman.2017.03.002

SILVA, J.D.C. et al. Effect of different tannery sludge compost amendment rates on growth, biomass accumulation and yield responses of Capsicum plants. Waste Management, v.30, p.1976-1980, 2010. Available from: <http://doi.org/10.1016/j. wasman.2010.03.011>. Accessed: Mar. 12, 2019. doi: 10.1016/j. wasman.2010.03.011

SOUSA, R.S. et al. Time-dependent effect of composted tannery sludge on the chemical and microbial properties of soil. Ecotoxicology, v.26, p.1366-1377, 2017. Available from: <http:// doi.org/10.1007/s10646-017-1861-9>. Accessed: Mar. 12, 2019. doi: 10.1007/s10646-017-1861-9.

STAMBULSKA, U.Y. et al. Chromium(VI) Toxicity in Legume Plants: Modulation Effects of Rhizobial Symbiosis. BioMed Research International, 5, 1-13, 2018. Available from: <http:// doi.org/10.1155/2018/8031213>. Accessed: Mar. 15, 2019. doi: $10.1155 / 2018 / 8031213$.

TEIXEIRA, K.R.G. Efeito da adiçao de lodo de curtume na fertilidade do solo, nodulação e rendimento de matéria seca do caupi. Ciência \& Agrotecnologia, v.30, p.1071-1076, 2006. Available from: <http://dx.doi.org/10.1590/S141370542006000600004>. Accessed: Jul. 19, 2019. doi: 10.1590/ S1413-70542006000600004.

USEPA. Acid digestion of sediments, sludge's and soils. Method 3050b EPA,United States Environmental Protection Agency, Washington, 1996. 